\title{
Inland Ship Modernization Index
}

\author{
Jing $\mathrm{Liu}^{1, \mathrm{a}}$ and Fangfang $\mathrm{JiaO}^{2, \mathrm{~b}}$ \\ ${ }^{1}$ China Waterborne Transport Research Institute, Beijing, 100088, China \\ ${ }^{2}$ China Waterborne Transport Research Institute, Beijing, 100088, China \\ a liujing@wti.ac.cn, ${ }^{\mathrm{b}}$ jiaofangfang@wti.ac.cn
}

\section{Keywords: Inland ship; Modernization; Standardization}

Abstract:Considering the process of inland waterway transport modernization and the practice of Chinese government "Inland ship standardization project" in recent years, this paper aims to study on the index system of inland ship modernization, which can be summarized as "safety, efficiency, green, and advance", and analyzes the relationship between modernization and standardization of inland ships.

\section{Introduction}

Inland Waterway Transport (IWT) plays an important role in China's social and economy development, especially in the Yangtze River Economic Belt. The National Council published "The instructions of development of the Yangtze River Economic Belt by relying on the Yangtze River Gold Waterway", and IWT became a national strategy. As it pointed out, IWT is favorable for constructing a modern comprehensive transport system, reshaping industrial layout, harmonizing development of regional economy, and implementing green development. For IWT system, ships provide the carrying capacity, so the modernization of ships has a great effect on the whole IWT modernization. [1-2] This paper will build a basic index system of the inland ship so as to provide a better understanding and promote IWT development and thus Yangtze River Economic Belt.

\section{Research Background}

After China's Reform and Opening up in 1978, the inland shipping market prospered, and many inland ship types with low technical and economic performance appeared. For example, the average tonnage of inland ships is no larger than a heavy truck. The first inland ship standardization began in 2003, when the Ministry of Transport (MOT) launched a project named "The great canal inland ship standardization demonstration". During this project, the government pays more than 1 billion Yuan subsidy, eliminate successfully nearly 40,000 cement made ship and hanging paddle machine ship in the Great Canal, the passing capacity and safety level is greatly improved. In 2009, the Yangtze River inland ship standardization project launched, in which the ships with a tonnage under 600GT and single hull tankers were prohibited to be operated in the Three Gorge area, and the total subsidy is over 1.6 billion. During 2009 to 2013, more than 7700 small and old ships were dismantled. In 2013, the ship standardization project was extended to the nationwide scope, and the ships with a tonnage under 200GT passing ship locks in the Great Canal, the single hull oil and chemical tankers, and high polluting ships must be converted or dismantled. During these projects, the MOT also developed 67 standard ship technological solutions, and the main ship dimension series coverall navigable rivers in China. At the same time, the government took both economic and 
administrative measures to promote the inland ship development. By the end of 2015, the average tonnage, the standardization level, the specialization level, and the green development level have been all greatly enhanced. This will give more promotion for the future inland ship modernization.

For the average tonnage, it reached 819DWT in 2015, nearly 7 times as big as in 2001, as show in table 1.

\begin{tabular}{|c|c|c|c|c|c|}
\hline & $\begin{array}{c}\text { Number } \\
\text { (thousand) }\end{array}$ & $\begin{array}{c}\text { DWT } \\
\text { (million tons) }\end{array}$ & $\begin{array}{c}\text { Average DWT } \\
\text { (tons) }\end{array}$ & $\begin{array}{c}\text { TEU } \\
\text { (thousnad } \\
\text { TEUs) }\end{array}$ & $\begin{array}{c}\text { Power } \\
\text { (MW) }\end{array}$ \\
\hline $\mathbf{2 0 1 5}$ & 152.5 & 124.94 & 819 & 270.5 & 32788.1 \\
\hline $\mathbf{2 0 1 0}$ & 165.7 & 74.36 & 449 & 128 & 24235.6 \\
\hline $\mathbf{2 0 0 5}$ & 195.8 & 44.81 & 228.88 & 52.9 & \\
\hline $\mathbf{2 0 0 1}$ & 200 & 21.46 & 107.29 & 8.8 & \\
\hline
\end{tabular}

Table 1.Inland ship analysis

For green development, the average energy consumption has greatly decreased. According to some statistics, in 2012, the oil consumption per thousand tonnages in Yangtze River area is $6.18 \mathrm{~kg}$, 44\% lower compared with that in 2007.

To meet the requirement of social and economic development, the government proposed that in 2020, the average tonnage of inland ship should reach 1200DWT nationwide, 2000DWT on the Yangtze River main stream, and 800DWT on the Great Canal. The safety, environmental protection, energy saving and emission reduction levels should achieve great progress, and average energy consumption per tonnage-mile and $\mathrm{CO} 2$ emission should decrease 5-10\% compared with those in 2015. Sewage discharge should be $100 \%$ qualified, and the ship and navigation infrastructure should be more harmonized. The crew living condition and outlook of ship should be better. Total standardization level should reach $70 \%$ nationwide, and $80 \%$ on the Yangtze River and the Pearl River basins. The final goal is to basically realize inland ship standardization, serialization, and modernization.

\section{Research Methods}

Based on the actual demand for inland ships and considering Chinese social and economic situation (such as safety and emission reduction), this research takes the index decomposition method to identify the basic concept and the detailed composition index, and gives specific description for each index.

\section{Concept of inland ship modernization}

There is a narrow and broad concept about the ship modernization. The narrow concept is the modernization of a single ship, which means to apply modern technologies and methods, such as ship design and building, haul equipment, clean energy, operating, and organizing in her life cycle to achieve "safety, efficiency, green, and advance". The broad concept extends the narrow one to the whole fleet of a country, which means to build a "safety, efficiency, green, and advance" fleet to meet various passenger and cargo shipping requirements, and to adopt navigation infrastructure with a specialized and advanced fleet. The core goal of this concept is to ensure the IWT system to be smooth, high-efficient, safe, and green-developed. This indicates the harmony development of people, IWT, and water resource. Inland ship modernization is a status when it does reach the level, 
and it also a developing process to keep pace with the time (1-1). This article focuses on the broad concept due to its significant meaning to the industry.

\section{The Index System of Inland Ship Modernization}

The main characters can be summarized as "safety, efficiency, green, and advance", which compose the first level of the index system.

Safety is the fundamental factor of modernization, and is the primary condition of all other factors. It means to use modern technologies to strengthen ship structure and ensure the safety of cargoes and passengers, and also use environmental security facilities to ensure environment safety. Although inland ship safety level is relatively much lower than road transport, the accident rate of inland transport is low. As inland ships use water to transport and the widely dispread village ferry ships are closely related to daily life, in case of accident, the direct loss of life and prosperity and even the side effect are high. According to statistics, in all water transport accidents exceeding 10 people dead or missing, $75 \%$ are related to ferry ship. At the same time, hazardous cargo transport in inland shipping is developed very quickly in recent years, and about 200 million tons of liquefied hazardous cargo throughputs in inland ports. If they exploded or leaked, it is very likely to become a disaster to water body. The modernization of safety requires an advanced ship inspection regulation and strict enforcement. But it is always a challenge to scientifically and economically determine a proper regulation level, which needs much investigation, especially when the inland waterway is upgrading. Sometimes this may even put an adverse effect on development more or less.

Efficiency is the mark of the vessel modernization. There are two economic measures of a transport mode: space and time. When the cargo is transported from one place to another, the space value is created; while when the cargo is transported punctually, the time value is created. As transport time is the weakness of the IWT, it is no doubt that efficiency means to improve punctuality, which will raise the improvement of service level. In the Yangtze River Economy Belt, the reliability, convenience and economy levels for inland shipping will be greatly improved, especially the inland ships will became more and more integrated to comprehensive transport system and be connected with rail and road, even airport. The detailed requirements for inland ship include:

I Requirement for enhanced reliability and predictability. Since modern logistics and production need punctuality, and ships must become more predictable, especially container inland ships.

I Improved efficiency and lower cost. Demand side is more sensitive to cost, so the lager ship size is just for this purpose.

I Lower cargo damage. Lean production relies on lower inventory more, and cargo damage may lead to the breakdown of the entire assembly line.

I Integrated with supply chain. Door to door logistics requires transport service to provide a complete supply chain service; inland shipping must use modern logistic ideas and be fully integrated with other transport modes.

The detailed indication of efficiency includes ship standardization and operation level.

Green is a requirement from modernization. A modern country is always a green developed country, and it requires a green transport mode. Although inland shipping is energy-efficient compared with other modes, the green advantage of inland shipping is absent, due to the slow market development and low level of regulation in pollution emission. For example, road transport 
began control air pollution in 1983, and the controlled indices cover $\mathrm{CO}, \mathrm{CH} 4$, particulate matters, NOx, and SOx. Whereas for inland shipping, the air pollution control began in 2008, 23 years later than road, and the index only covers NOx, and its level is 5-10 times as high as that of road. The Sox emission level of inland shipping is hundred times as high as that of road. Moreover, there are lots of inland ships using non-standard fuel. Some container ships even use HFO with 3.5\% of SOx. In recent years, liquefied nature gas began to be used in inland ships, but due to economic reason and lack of refueling facility, the development is very slow. At the end of 2015, there were less than 100 LNG-powered inland ships in operation. This also happens in European inland shipping, and they also began to take some measures to control the air pollution of inland ships, including using LNG and some after-treatment measures for exhaust gas, for example SCR. From technical point of view, the index of green includes using clean energies such as LNG, electricity, and solar energy to reduce emission and save energy, through sustainable and recycle development ideas.

Advance is the driving force of modernization. Technology is very important to promote the economic performance and competitiveness of a ship. Using advanced technologies is vital to enhance utilization of ship locks and channels, reduce congestion and accidents (1-2), and most important, reduce noises and water pollution. In a history point of view, the inland ship technology in China is not so advanced as the sea ship technology, and the R\&D investment is relatively low. There are various reasons for this. One of them is the scattered market structure, which causes fierce competition and the enterprises fail to adapt new technology. Another important reason is the insufficient understanding of the inland shipping from the country: the government does not put enough R\&D investment in this area. But it was believed that with the increase of average income in China and more concerns about air quality, this situation will change soon. In detail, advance means modern design methods, and encouragement of using new materials, new technologies and crafts, and advanced equipment. The Inland Ship Modernization Index System is shown in Fig. 1

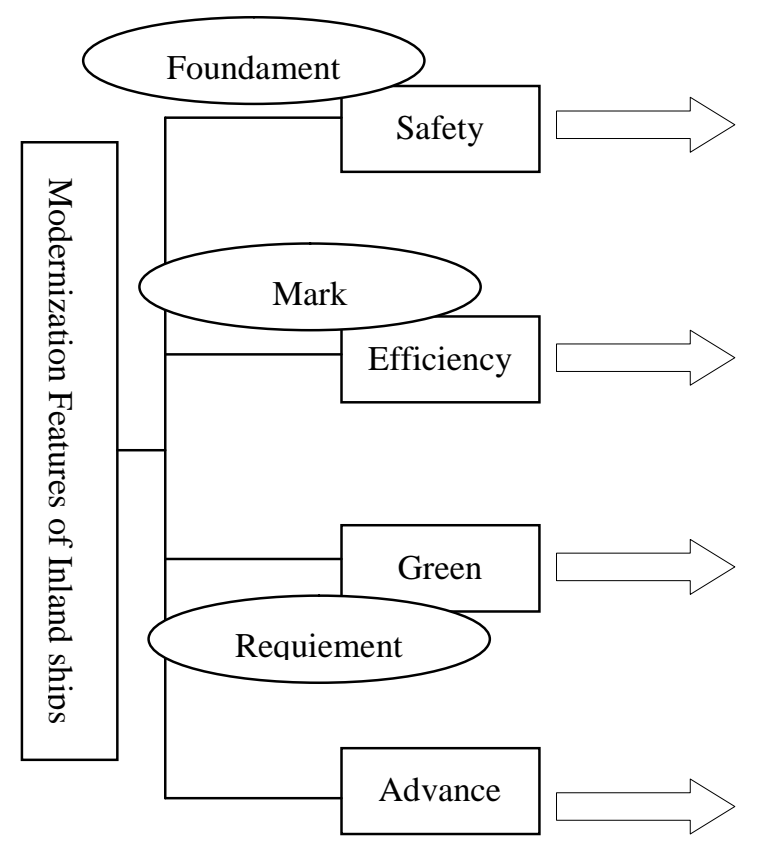

Fig. 1. Inland

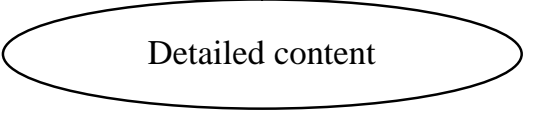

I Excecute the regulations and standards of shipbuilding strictly

I Standardization of ship types

I Modernization of energy performance management

Modernization of transport organization

Application of clean energies

Development of resource saving and recycling technologies

Modernization of design concept

Modernization of design methods

Application of new technologies

Application of new materials

Application of new processes

Application of advanced equipments 


\section{Relationship between Modernization and Standardization}

From development experience, standardization is the approach to realize economies of scale and modernization. Since the MOT published regulations to promote inland ship standardization, the projects have covered every area, including the Great Canal, the Yangtze River and the Three Gorge, and the Pearl River. The achievement is fruitful. The market structure, technology level, safety, and environmental protection level have been greatly enhanced. This implies that standardization plays a very important role in promoting modernization.

Logically speaking, modernization is in a high level over standardization. Moreover, modernization also includes advanced technologies, equipment, and operations. However, modernization is a shifting concept, just like standardization, especially in China.

\section{Conclusions}

To promote the IWT further, it is important to take comprehensive consideration of the index system of its modernization. This paper gives a clear concept about inland ship modernization for academic use, and points out the direction of its future development.

\section{Reference}

[1] GaoHongtao, Zou Xia, Zhang Danyu. Study on the static and dynamic evaluation index system of highway transportation modernization [J]. Highway traffic science and technology.2006

[2] Liao Zhen, JiaJunfang. Evaluation of modernization development mode of railway technical equipment [J]. Journal of Beijing Jiaotong University, 2006

[3] Li Biying. Research on the green ship and its evaluation index system[J]. China Shipbuilding industry, 2008

[4] The comparison of virtue inland waterway transport development [J]. Traffic and transportation, 2007

[5] Zhu Xiaochuan. The Thinking about the development of water transport in Jiangsu learn from the experience of the Rhine shipping [J]. China water transport, 2007 